\title{
Otocinclus cocama, a new uniquely colored loricariid catfish from Peru (Teleostei: Siluriformes), with comments on the impact of taxonomic revisions to the discovery of new taxa
}

\author{
Roberto E. Reis
}

A new, uniquely colored species of the loricariid catfish genus Otocinclus, O. cocama is described from a tributary to the lower río Ucayali in northern Peru. The new species is distinguished from other Otocinclus species by two putatively autapomorphic features, the distinct color pattern, consisting of vertically elongated blotches spanning from the dorsal midline to the ventral border of flanks, and by a complete lateral line. The phylogenetic relationships of the new species are investigated and it is apparently more closely related to a clade formed by $O$. huaorani, $O$. bororo, $O$. mariae, and $O$. mura. Comments on the impact of taxonomic revisions for the discovery and description of previously undetected biodiversity are also presented.

Uma nova espécie de bagre loricariídeo de coloração única do gênero Otocinclus, O. cocama, é descrita de um afluente do baixo río Ucayali no norte do Peru. A nova espécie se distingue das demais espécies de Otocinclus por dois caracteres supostamente autopomórficos, o padrão de coloração diferenciado, que consiste em marcas alongadas verticalmente desde a linha média dorsal até a porção ventral dos flancos, e por uma linha lateral completa. As relações filogenéticas da nova espécie são investigadas e ela é aparentemente mais proximamente relacionada ao clado formado por $O$. huaorani, O. bororo, $O$. mariae e $O$. mura. Ao final, são apresentados comentários sobre o impacto de revisões taxonômicas no descobrimento e descrição de biodiversidade previamente não detectada.

Key words: Systematics, Taxonomy, South America, Neotropical, Loricarioidei, Loricariidae, Phylogeny.

\section{Introduction}

The genus Otocinclus has 15 species and a few other undescribed are already known to scientists. It was recently revised by Schaefer (1997) who recognized 13 species as valid, five of which were originally described in that paper. The species of Otocinclus are widely distributed in cis-Andean South America, from northern Venezuela to northern Argentina, usually inhabiting small to medium sized water bodies, often associated with marginal vegetation.

Otocinclus is the most basal genus in the tribe Hypoptopomatini (Schaefer, 1998). It's monophyly being supported by seven uniquely derived features (Schaefer, 1997).

A 55-year span has occurred between the description of O. macrospilus Eigenmann \& Allen, 1942 and Schaefer's (1997) revision of Otocinclus, where five new species were described. After 1997, four additional species have already been found,
O. tapirape Britto \& Moreira, 2002, O. mimulus Axenrot \& Kullander, 2003, the one being described in the present paper, and another, yet undescribed, species from Peru and Colombia. This pattern of new species being described soon after the publication of a revision is relatively common and will be discussed below.

During the course of an expedition of the Ucamara Project in the lower río Ucayali, we found the specimens used in this paper with aquarium fish collectors in the locality of Jenaro Herrera. The species described herein is already known and very popular in the aquarium trade at least since 2000, where it is known as Otocinclus "zebra". The aim of this paper is to formally describe and make a scientific name available to this species.

\section{Material and Methods}

Most of the methods employed in this paper follow those

Laboratory of Ichthyology, Pontifícia Universidade Católica do Rio Grande do Sul, Av. Ipiranga, 6681, P.O.Box 1429, 90619-900 Porto Alegre, RS, Brazil. e-mail: reis@pucrs.br 
of Schaefer (1997), except as noted below. Digital images of lateral aspect of body and dorsal view of head of individual specimens were generated using a video digitizer. Morphometric data were acquired as homologous (geometric) landmark coordinates with the software TPSDig v. 1.11 by James Rohlf. In addition to the 25 landmarks described by Schaefer (1997), the end of the caudal peduncle (landmark 26) and two extra points on a millimetric ruler were digitized. Standard length, as well as other interlandmark distances, was obtained with the software LMDis v. 1.0 by R. E. Reis. Four measurements, in addition to the 13 presented by Schaefer (1997), and standard length, were obtained as follows: standard length [interlandmark distance 1-26], pre-dorsal length [1-8], pre-pelvic length [1-10], pre-anal length [1-12], and snout length [1-13]. Specimens examined are housed in the following institutions: AMNH, American Museum of Natural History, New York; MCP, Museu de Ciências e Tecnologia, Pontifícia Universidade Católica do Rio Grande do Sul, Porto Alegre, and MUSM, Museo de Historia Natural, Universidad Nacional Mayor de San Marcos, Lima.

\section{Otocinclus cocama, new species} Figs. 1-4

Holotype. MUSM 20686, $43.5 \mathrm{~mm}$ SL, female, quebrada Yanayacu (approx. $04^{\circ} 55^{\prime} \mathrm{S}, 073^{\circ} 43^{\prime} \mathrm{W}$ ), tributary to the caño of the cocha Supay in Jenaro Herrera, Provincia Requena, Departamento Loreto, Peru; Jan 2004, employees of Mr. Grimaldo Mendoza Oviedo collected.

Paratypes. MUSM 20687 (5, 29.6-43.2 mm SL), MCP 34842 (8, + 2 c\&s, 29.8-40.7 mm SL + 1 tissue sample), and AMNH 233730 (3, 36.4-43.8 mm SL), all collected with the holotype.

Diagnosis. The following putative autapomorphies distinguish Otocinclus cocama from all its congeners: (1) a unique, distinct color pattern consisting of vertically elongated blotches spanning from the dorsal midline to the ventral border of flanks (Figs. 1 and 4), and (2) a complete lateral line, without the gap plates (midbody plates without lateral line perforations) present in other Otocinclus. In addition, the new species can be distinguished from most other Otocinclus by its high number of teeth (30-45 in premaxilla and 23-36 in dentary $v s$. 10-29 and 9-22 in most species except $O$. huaorani Schaefer, 1997 [18-34 and 16-30], O. mura Schaefer, 1997 [22-30 and 1827], and $O$. bororo Schaefer, 1997 [17-31 and 17-26]). From $O$. huaorani, O. mura, and $O$. bororo, the new species can be further distinguished by the presence of a small metapterygoid channel ( $v s$. absent in these three species), and by having one $\mathrm{W}$-shaped mark in the caudal fin ( $v s$. two W-shaped mark in the above three species).

Description. Standard length of examined specimens 29.6$43.8 \mathrm{~mm}$ SL. Other morphometric data presented in Table 1, counts in Table 2.

Body moderately short, robust. Dorsal profile of head from snout tip to dorsal-fin origin straight to slightly convex; slightly concave between snout tip and nares. Dorsal profile of trunk from dorsal-fin origin to caudal peduncle straight to slightly concave. Ventral profile of head and abdomen from snout tip to anus straight, transversely flat. Ventral profile of trunk slightly concave between anal-fin origin and caudal fin. Snout rounded, rostrum convex; region anterior to nares slightly depressed. Greatest body depth at dorsal-fin origin, $19.8-24.9 \%$ SL. Body between pectoral and pelvic-fin origins ovoid in cross section; trunk ovoid and compressed in cross section anteriorly, progressing to slightly rectangular towards caudal fin. Dorsal and ventral surface of caudal peduncle slightly flattened; margins of dorsal and ventral lateral plate series bearing enlarged odontodes forming ridge-like keels, especially pronounced in smaller individuals.

Head depressed. Eyes moderately large, visible from ventral side. Orbit length 18.5-25.9\% HL; positioned approximately midway between snout tip and compound pterotic posterior process; distance between orbit margin and ventral surface of head less than half orbit length. Dorsal iris diverticulum absent. Lateral ethmoid with small subnasal lamina.

Dorsal fin II, 7; origin approximately at or slightly beyond vertical through pelvic-fin origin; when depressed, reaching to vertical line through end of anal-fin base. Nuchal plate narrow, roughly triangular, articulated with $\mathrm{V}$-shaped, dorsalfin spinelet; dorsal-fin locking mechanism functional. Pectoral fin I, 6; reaching to middle of pelvic fin length. Pectoral pore present on skin above pectoral-fin insertion, below lateral process of cleithrum. Pelvic fin I, 5; when depressed reaching beyond anus but not reaching anal-fin origin; skin flap on dorsal surface of unbranched pelvic-fin ray of males. Anal fin I, 5. Caudal fin I, 7/7, I; upper caudal fin lobe slightly longer than lower one. Dorsal procurrent rays 4-5; ventral procurrent rays 5 (in two c\&s specimens).

Total plates in middle lateral series 22-24, usually 23. Lateral line almost complete, pored tubes visible from compound pterotic to caudal peduncle; 1-3 most posterior plates in middle series without lateral line. Total vertebrae 28 (in two c\&s specimens). Abdomen completely covered by paired series of 4-7 (usually 5-6) large, sickle-shaped lateral plates, intervening region covered by smaller, squarish to rounded plates of irregular size and spacing, usually arranged in 1-2 longitudinal series; median plates extending posteriorly beyond lateral abdominal plate series to middle of branched pelvic fins forming triangular pre-anal shield. Subopercular plate present and well developed. Pelvic girdle completely exposed ventrally and covered with odontodes; arrector fossae closed.

Odontodes evenly distributed and regularly arranged on head and body. Enlarged odontodes on anterior and lateral snout margin, dorsal-, pectoral-, and pelvic-fin spines, and in row along lateral corners of slightly flattened dorsal and ventral caudal peduncle region. Males with small contact organ formed by swirl of odontodes (Fig. 3) at ventral margin of caudal fin base.

Premaxillary teeth 30-45, mandibular teeth 23-36. Oral disk 


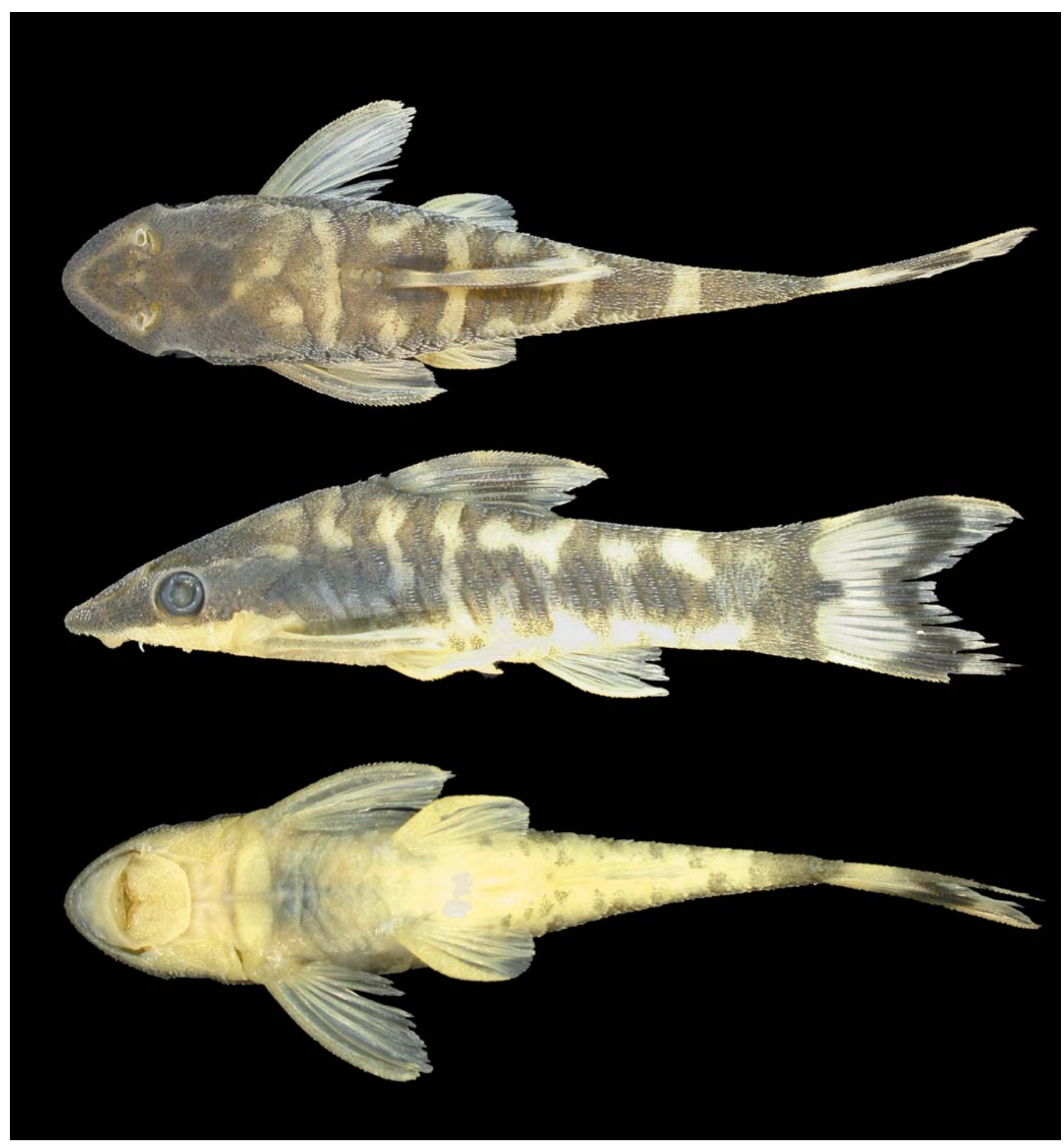

Fig. 1. Otocinclus cocama, holotype, MUSM 20686, 43.5 mm SL, female, quebrada Yanayacu, Jenaro Herrera, Loreto, Peru.

roundish, covered with small papillae; margin of lower lip heavily fringed; maxillary barbel short, its free portion about one fourth to one third of orbit length.

Color in life. Ground color of head and dorsum bluish white to slightly creamy yellowish. Dorsum of head and snout between nares black. Lateral portions of snout and postorbital region of head also black, leaving narrow, V-shaped white band beginning at snout tip, passing through nares and above orbits, and progressing laterally through compound pterotic. Ventral margin of snout darkened but head otherwise white or pale yellowish ventrally. Medial portions of compound pterotic, parietosupraoccipital, and first pre-dorsal plate black or dark gray. Color pattern of dorsum of body and flanks formed by four black or dark gray, saddle-shaped blotches; one at origin of dorsal fin, second behind dorsal-fin base, third between dorsal and caudal fins, and fourth at base of caudal fin. These dorsal markings always prolonged ventrally into flanks, in wide, vel- 


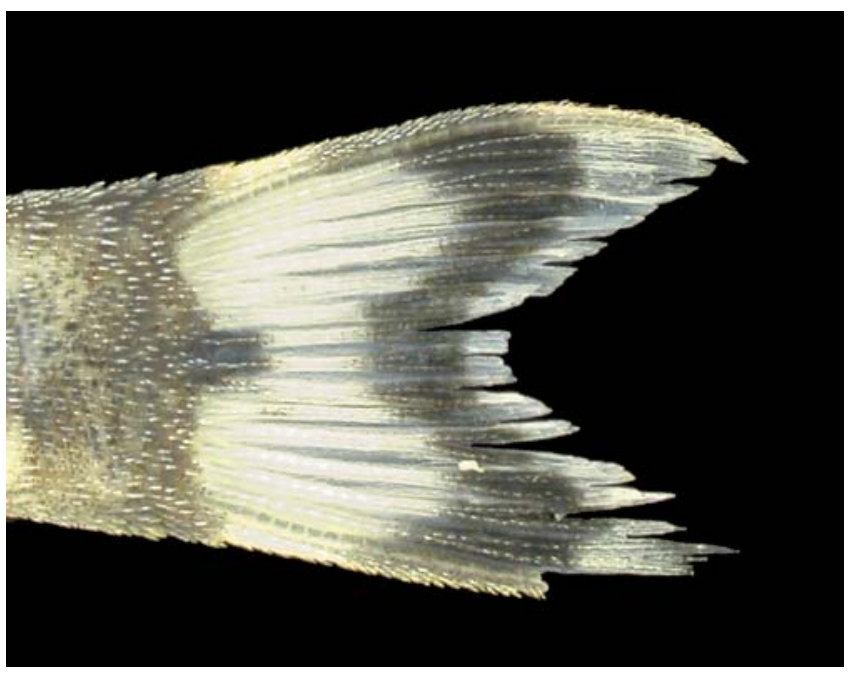

Fig. 2. Caudal fin of Otocinclus cocama, holotype, MUSM 20686, $43.5 \mathrm{~mm}$ SL, female, quebrada Yanayacu, Jenaro Herrera, Loreto, Peru.

vet black, transverse bands, usually duplicated or forming roundish blotches in large specimens (Fig. 4). Additional layer of dark gray pigment in subjacent skin form with lateral blotches inconspicuous lateral stripe. Some pigmentation sometimes scattered or forming few dots on lateral portion of belly, between pelvic and anal fins, and on ventral face of caudal peduncle. Fins mostly hyaline. Outer face of pectoral spine pigmented with black; small patch of black chromatophores on unbranched pelvic- and anal-fin rays, sometimes on first branched anal-fin ray. Dorsal fin black at origin and with wide transverse, roughly triangular black band from spine to last branched ray, but leaving base and tip of rays white. Black spot on dorsal-fin spine and first branched ray sometimes divided in two patches. Caudal fin with $\mathrm{W}$-shaped vertical band in distal half, but leaving narrow hyaline band at margin. Base of two central caudal-fin rays usually black, as prolongation of last caudal peduncle black blotch (Fig. 2).

Color in alcohol. Color pattern as in living specimens, but white background turns into pale yellowish and black markings become faded or brownish (Fig. 1).

Sexual dimorphism. Males of Otocinclus cocama are less common and smaller than females (the only two males examined out of 20 specimens are 30.4 and $36.2 \mathrm{~mm} \mathrm{SL}$ ). As usually among hypoptopomatines, males of Otocinclus cocama have a conical urogenital papilla behind the anal tube, which is not present in females. Also, males possess a skin flap on the dorsal surface of the unbranched pelvic-fin ray, which is absent in females. Finally, males have a small contact organ formed by an odontode swirl (Fig. 3) at ventral margin of the caudal peduncle, near the caudal fin base.

Distribution. Otocinclus cocama is so far known from its type locality, in the quebrada Yanayacu, near Jenaro Herrera,
Loreto, Peru (Fig. 5). This species has been in the aquarium trade since early 2001 and is quite common in the aquarium shops in Iquitos, Peru, being likely to occur in other places in lower Ucayali and Marañon rivers.

Ecology. The type locality of Otocinclus cocama is a medium size creek, with clear water and lots of marginal vegetation. According to the collectors, the fishes are usually caught by seining and dipnetting in that vegetation.

Etymology. Otocinclus cocama is named after the CocamaCocamilla Indians that used to be dominant in the lower Ucayali and Marañon rivers. The present estimations point to a little more than 10,000 people in Peru, plus a few hundreds in Colombia and Brazil. During the last century, the Cocama culture has been mostly assimilated by the regional society, losing their language and identity, being thus threatened as a group. The name is treated as a noun in apposition.

\section{Discussion}

Otocinclus cocama is readily distinguished from all other Otocinclus species by its complete lateral line and higher number of teeth, as detailed in the diagnosis above. The most striking feature, however, is its unique color pattern, which caused aquarists worldwide to call it Otocinclus "zebra" (Wendenburg, 2001; Evers \& Seidel, 2002).

The phylogenetic relationships of Otocinclus cocama was investigated, although a full phylogenetic analysis is not presented here, and is deferred to a future paper by Pablo Lehmann, who is describing another new Otocinclus species. Otocinclus cocama is most probably closely related to the clade "B" of Schaefer (1997). It shares all characters

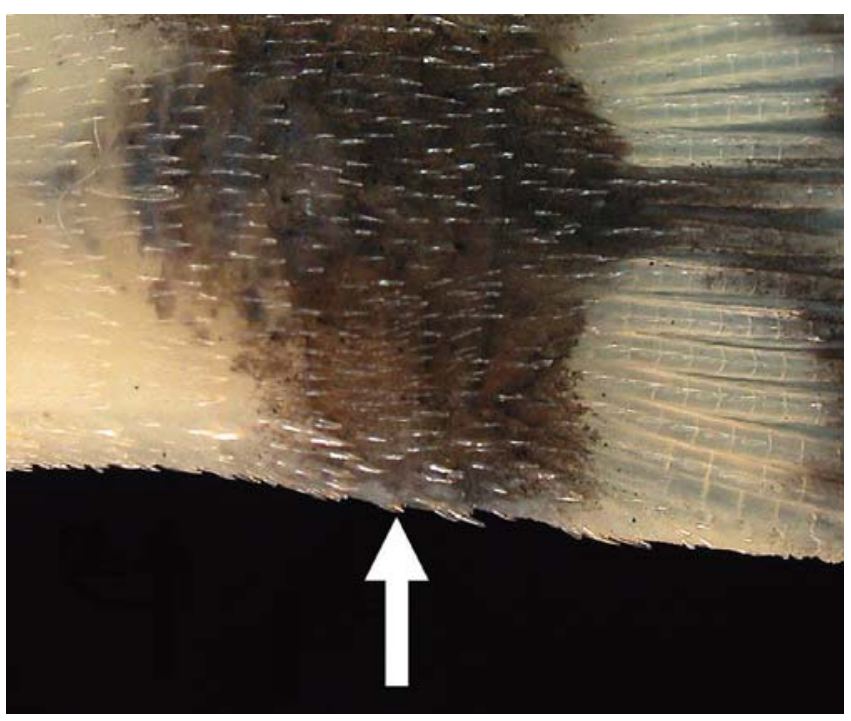

Fig. 3. Caudal peduncle of Otocinclus cocama, paratype, MCP 34842, $36.2 \mathrm{~mm}$ SL. Odontode swirl forming a contact organ (arrow), a male sexual dimorphism in the arrangement of odontodes near the caudal-fin base. 


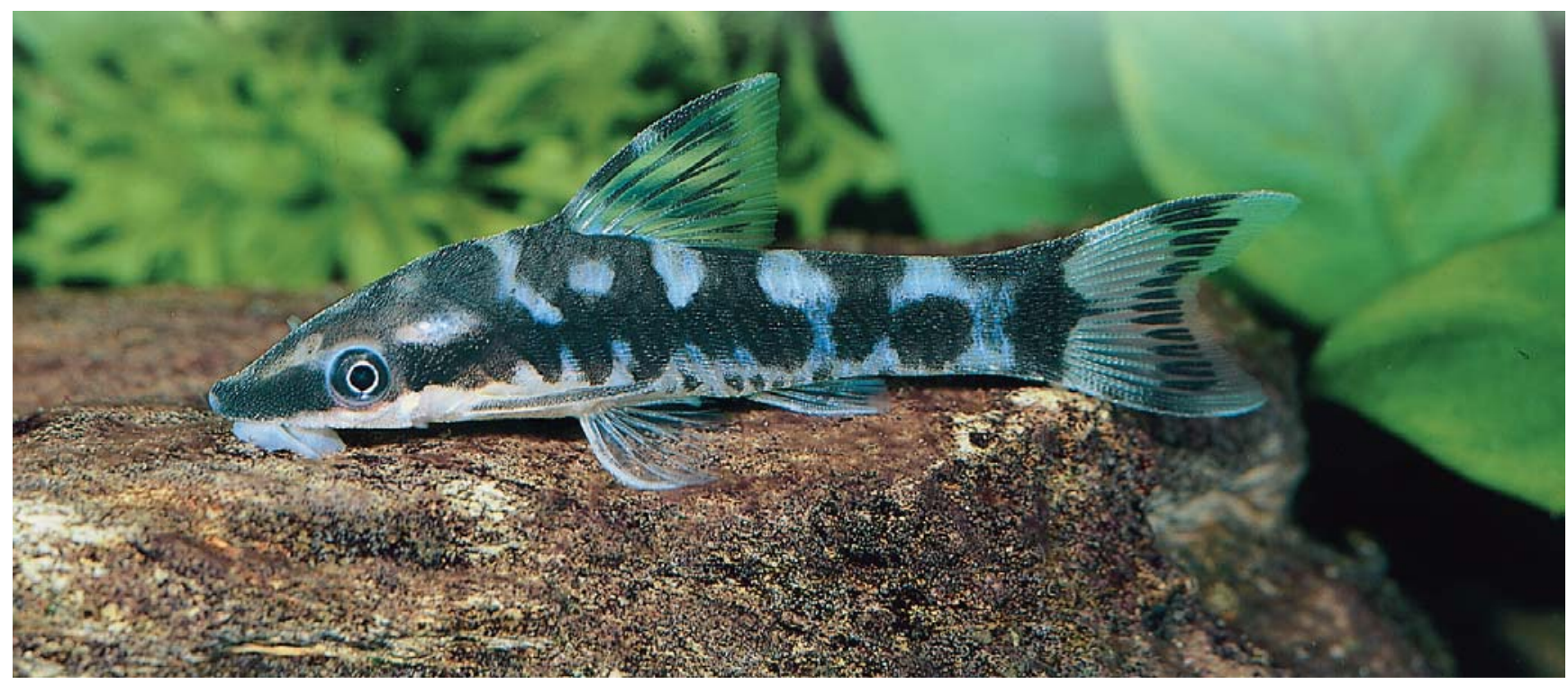

Fig. 4. Live specimen of Otocinclus cocama, collected in Peru in 2000; not preserved. Photo by Ingo Seidel.

(but characters 6 and 7 not examined) that are synapomorphic to the genus, according to Schaefer (1997): (1) Mesethmoid bifurcate, with expanded anterolateral buttress [character 1 of Schaefer (1997)]; (2) absence of the ventral lateral ethmoid ridge [character 3]; first epibranchial flange present [character 9]; and (3) esophageal diverticulum expanded as accessory air bladder [character 26]. It also possesses at least part of the derived features of Schaefer's (1997) vestitus clade: (1) Lateral ethmoid with expanded subnasal lamina [character 2]. Two other features of the vestitus clade are ambiguous in the new species: (2) a reduced number of vertebrae [character 10] does not occur in O. cocama, which has 28 vertebrae. This high vertebrae count can be either reversed and autapomorphic in O. cocama, or be a synapomorphy of $O$. cocama and $O$. mura; (3) twenty-three of fewer total lateral plates [character 15] is also not present in $O$. cocama. The alternative state of having 24 or more plates, as in $O$. affinis Steindachner, 1877, O. flexilis Cope, 1894, and $O$. mura, however, is also not the case, as the new species has 22-24 lateral plates in the middle series.

Likewise, characters defining Schaefer's (1997) clade "A" are present in O. cocama: (1) nuchal plate roughly triangular, with lateral margins reduced [character 11]; and (2) caudal fin with paired W-shaped marks [character 22]. Otocinclus cocama, however, possess only one, well defined, W-shaped mark in the caudal fin, probably representing a second derived state for this character. Whether the new species lost the anterior $\mathrm{W}$-shaped mark or the two marks became fused in uncertain. Of the two characters defining the "orbis" clade, only one is present in O. cocama: (1) iris diverticulum absent [character 25]. The other character used by Schaefer to define the "orbis" clade was (2) the loss of the metapterygoid channel [character 5]. Otocinclus cocama has a small laminar shelf on the metapterygoid, forming a small channel. This metapterygoid channel can be either reversed and autapomorphic in $O$. cocama, or be a synapomorphy of $O$. cocama and $O$. mariae.

One single character was used to define the clade "B", and that is an increased number of teeth in both premaxilla and dentary [character 27]. Otocinclus cocama has the highest teeth counts among Otocinclus species, and thus the derived condition for this character. Finally, Schaefer's clade "E" (O. bororo, O. mariae, and O. mura) is defined by one feature: eight or more canal-bearing plates in the anterior field of the lateral line [character 18]. Otocinclus cocama has a complete lateral line, without the typical gap plates of other Otocinclus species. Possessing a complete lateral line can be viewed as having more than eight anterior field canalbearing plates, thus including $O$. cocama in clade " $E$ ". More likely, however, having a complete lateral line is a second, derived state for character 18 , and to resolve the relationships of $O$. cocama in the clade "B", additional characters will be necessary.

Besides the obvious benefits taxonomic revisions provide for the inventory and understanding of biodiversity, they play another, not always acknowledged, significant role in the discovery and description of additional biodiversity. Last species of Otocinclus described prior to Schaefer's (1997) revision was O. macrospilus. A 55-year span has occurred between the description of $O$. macrospilus and Schaefer's revision of Otocinclus. After 1997, however, four additional new species have already been detected, $O$. tapirape, O. mimulus, O. cocama, and another species from Peru and Colombia being described by Pablo Lehmann (pers. comm.). Fish groups that deserve a taxonomic revision are usually confuse, with unsettled taxonomies, and with difficult to identify species, features that often preclude the unambiguous detection of undescribed taxa. Taxonomic revisions of such groups allow researchers to find and more easily identify previously undetected diversity, because 
information becomes clearly arranged and organized in the revisions.

Additional, similar cases of previously undetected diversity of fishes being described soon after the publication of a taxonomic revision are present in the literature. Curimata acutirostris Vari \& Reis, 1995 was described six years after the revision of Curimata by Vari (1989). Last Curimata species described prior to the works of Vari $(1984,1989)$ was $C$. murieli Allen in Eigenmann \& Allen, 1942. Xenurobrycon polyancistrus Weitzman, 1987 was described soon after the revision of Xenurobrycon by Weitzman \& Fink (1985). Last and only species described prior to the revision was $X$. macropus Myers \& Miranda Ribeiro, 1945. Pogonopoma obscurum Quevedo \& Reis, 2002 was published four years after the revision of the tribe Rhinelepini by Armbruster (1998). Last Rhinelepini species described prior to Armbruster's revision was Monistiancistrus carachama Fowler, 1940 (syn. Pseudorinelepis genibarbis [Valenciennes, 1840]). Gymnogeophagus setequedas Reis, Malabarba \& Pavanelli, 1992, and Gymnogeophagus che Casciotta, Gómez \& Toresanni, 2000, were both described after the revision of Gymnogeophagus by Reis \& Malabarba (1988). Last species of Gymnogeophagus described prior to the revision was G. cyanopterus Miranda Ribeiro, 1918 (syn. G. balzanii [Perugia, 1891]).

Previously undetected diversity detected and described soon after taxonomic revisions is also found broadly among other taxa. For example, among Neotropical spiders, Acacesia graciosa Lise \& Braul Jr., 1995 was described immediately after a revision of Acacesia by Glueck (1994). Last species of Acacesia described prior to Glueck's revision was A. pentagona Caporiaco, 1954 (syn. A. cornigera Petrunkevitch, 1925). Another example among Neotropical snakes is the descriptions of Echinanthera cephalomaculata Di-Bernardo, 1994 and E. cephalostriata Di-Bernardo, 1996, published soon after the revision of Echinanthera by Di-Bernardo (1992). Last species of Echinanthera described prior to the revision was Liophis insignissimus Amaral, 1929 (syn. E. persimilis [Cope, 1869]).

For this reason, taxonomic revisions of genera and other supraspecific taxa play a double role in our understanding of
Table 1. Descriptive morphometrics of Otocinclus cocama. Values are given for the holotype and ranges given for the 16 remaining specimens. $\mathrm{SOC}=$ parieto-supraoccipital posterior process $; \mathrm{SD}=$ standard deviation; $\mathrm{Hol}=$ holotype.

\begin{tabular}{lcccccc}
\hline Character & Hol. & N & Low & High & Mean & SE \\
\hline Standard length (mm) & 43.5 & \multicolumn{6}{l}{16} & 29.6 & 43.8 & 38.2 & 4.7 \\
& \multicolumn{7}{c}{ Percents of } & standard length \\
Head length & 26.6 & 16 & 27.8 & 38.6 & 30.9 & 2.8 \\
Body depth & 23.4 & 16 & 19.8 & 24.9 & 22.9 & 1.5 \\
Trunk depth at Anal origin & 22.1 & 16 & 18.6 & 21.8 & 20.4 & 0.8 \\
Caudal peduncle depth & 17.2 & 16 & 15.6 & 17.3 & 16.4 & 0.6 \\
SOC to Dorsal origin & 13.9 & 16 & 9.2 & 13.6 & 11.1 & 1.3 \\
Cleithrum to pelvic origin & 12.1 & 16 & 10.8 & 13.9 & 12.5 & 0.9 \\
Pelvic to anal origin & 19.8 & 16 & 18.3 & 20.7 & 19.7 & 0.7 \\
Trunk length & 43.1 & 16 & 39.3 & 44.0 & 42.0 & 1.2 \\
Predorsal length & 44.4 & 16 & 43.6 & 45.7 & 44.8 & 0.7 \\
Prepelvic length & 43.1 & 16 & 42.6 & 46.1 & 43.9 & 1.0 \\
Preanal length & 62.9 & 16 & 61.8 & 65.6 & 63.4 & 1.2 \\
& \multicolumn{7}{c}{ Percents of head length } & \\
Snout width & 38.8 & 16 & 27.7 & 40.3 & 36.0 & 2.9 \\
Interorbital width & 70.7 & 16 & 52.6 & 66.7 & 61.1 & 3.9 \\
Internasal width & 26.4 & 16 & 20.3 & 24.9 & 22.5 & 1.4 \\
Nares diameter & 14.1 & 16 & 11.4 & 15.3 & 12.7 & 1.0 \\
Snout length & 50.5 & 16 & 37.3 & 48.9 & 43.9 & 2.8 \\
Orbit length & 25.9 & 16 & 18.5 & 25.8 & 22.8 & 1.7 \\
\hline
\end{tabular}

the biodiversity, settling the current taxonomic and nomenclatural situation of a given taxon, and thus fostering the discovery of additional undescribed diversity.

\section{Acknowledgements}

I am much indebted to Hernán Ortega (MUSM) for his help in locating information on the Cocama Indians and other topics, to Rainer Stawikowski for locating the photograph of the living specimen, and to Ingo Seidel, for allowing me to use his superb photo of the living fish. Arno Lise and Marcos Di Bernardo helped locating literature. Marcelo Britto and an anonymous reviewer offered valuable suggestions to the manuscript. The fieldwork associated with this paper was supported by the Ucamara Project (NSF-DEB 0215388) and the All Catfish Species Inventory (NSF-DEB 0315963). The author is partially supported by CNPq (Process \# 305344/87-0).

Table 2. Frequency distribution and summary statistics for meristics of Otocinclus cocama. Holotype values are marked with an asterisk. $\mathrm{N}=$ number of individual counted, $\mathrm{SE}=$ standard error of the mean; $* *=$ counted in c\&s specimens

\begin{tabular}{|c|c|c|c|c|}
\hline Character & Frequency Distribution & $\mathrm{N}$ & Mean & SE \\
\hline Left total lateral plates & $23\left(11^{*}\right) 24(6)$ & 17 & 23.3 & 0.12 \\
\hline Right total lateral plates & $22(1) 23\left(15^{*}\right) 24(1)$ & 17 & 23.0 & 0.09 \\
\hline Left lateral abdominal plates & $4(1) 5(5) 6(8) 7\left(3^{*}\right)$ & 17 & 5.8 & 0.19 \\
\hline Right lateral abdominal plates & $4(2) 5(7 *) 6(7) 7(1)$ & 17 & 5.4 & 0.19 \\
\hline Left premaxillary teeth & $30(2) 31(1) 34(1) 35(2) 37\left(3^{*}\right) 38(1) 39(1) 44(1)$ & 12 & 35.6 & 1.17 \\
\hline Right premaxillary teeth & $30(2) 32(1) 34(1) 36(2) 38(1) 39(1) 40(2) 41(1) 45\left(1^{*}\right)$ & 12 & 36.7 & 1.34 \\
\hline Left mandibular teeth & $23(1) 27(2) 29(1) 30(1) 31(1) 32(2) 33(1) 34(1) 36\left(1^{*}\right)$ & 11 & 30.4 & 1.11 \\
\hline Right mandibulary teeth & $24(2) 27(1) 28(1) 29(1) 31(3) 33(1) 34(1) 35\left(1^{*}\right)$ & 11 & 29.7 & 1.12 \\
\hline Dorsal procurrent rays $* *$ & $4(1) 5(1)$ & 2 & 4.5 & - \\
\hline Ventral procurrent rays $* *$ & $5(2)$ & 2 & 5.0 & - \\
\hline Total vertebrae $* *$ & $28(2)$ & 2 & 28.0 & - \\
\hline
\end{tabular}




\section{Literature Cited}

Armbruster, J. W. 1998. Phylogenetic relationships of the suckermouth armored catfishes of the Rhinelepis group (Loricariidae: Hypostominae). Copeia, 1998(3): 620-638.

Di-Bernardo, M. 1992. Revalidation of the genus Echinanthera Cope, 1894, and its conceptual amplification (Serpentes, Colubridae). Comunicações do Museu de Ciências e Tecnologia da PUCRS, série Zoologia, 5: 225-256.

Evers, H.-G. \& I. Seidel. 2002. Wels Atlas. Vol. 1. Mergus, Melle, 860p.

Glueck, S. 1994. A taxonomic revision of the orb weaver genus Acacesia (Araneae: Araneidae). Psyche, 101: 59-98.

Quevedo, R \& R. E. Reis. 2002. Pogonopoma obscurum: a new species of loricariid catfish (Siluriformes: Loricariidae) from southern Brazil, with comments on the genus Pogonopoma. Copeia, 2002(2): 402-420.

Reis, R. E. \& L. R. Malabarba. 1988. Revision of the Neotropical cichlid genus Gymnogeophagus Ribeiro, 1918, with descriptions of two new species (Pisces, Perciformes). Revista Brasileira de Zoologia, 4: 259-305.

Schaefer, S. A. 1997. The Neotropical cascudinhos: Systematics and biogeography of the Otocinclus catfishes (Siluriformes: Loricariidae). Proceedings of the Academy of Natural Sciences of Philadelphia, 148: 1-120.

Schaefer, S. A. 1998. Conflict and Resolution: Impact of new taxa on phylogenetic studies of the Neotropical cascudinhos (Siluroidei: Loricariidae). Pp. 375-400 In:
Malabarba L. R., R. E. Reis, R. P. Vari, Z. M. S. Lucena \& C. A. S. Lucena. (Eds.). Phylogeny and Classification of Neotropical Fishes. Edipucrs, Porto Alegre, 609p.

Vari, R. P. 1984. Two new fish species of the genus Curimata (Pisces: Curimatidae) from Venezuela. Acta Biologica Venezolana, 11: 27-43.

Vari, R. P. 1989. Systematics of the Neotropical characiform genus Curimata Bosc (Pisces: Characiformes). Smithsonian Contributions to Zoology, 474: i-iii + 1-63.

Vari, R. P. \& R. E. Reis. 1995. Curimata acutirostris, a new fish (Teleostei: Characiformes: Curimatidae) from the rio Araguaia, Brazil: Description and phylogenetic relationships. Ichthyological Exploration of Freshwaters, 6(4): 297-304.

Weitzman, S. H. \& S. V. Fink. 1985. Xenorobryconin phylogeny and putative pheromone pumps in glandulocaudine fishes (Teleostei: Characidae). Smithsonian Contributions to Zoology, 421: i-iii + 1-121.

Wendenburg, H. 2001. Die kleinen und etwas anderen Harnischwelse. Pp. 33-35. In: Stawikowski, R. (ed.). Harnischwelse. Die Aquarien- und Terrarienzeitschrift, Sonderhelf 2. Eugen Ulmer, Stuttgart.

Received June 2004 Accepted August 2004 